\title{
INFLUENCE OF STORAGE SOLUTION ON ENAMEL DEMINERALIZATION SUBMITTED TO PH CYCLING
}

\author{
INFLUÊNCIA DA SOLUÇÃO DE ARMAZENAGEM NA DESMINERALIZAÇÃO \\ DO ESMALTE SUBMETIDO À CICLAGEM DE PH
}

Juliana Silva MOURA ${ }^{1}$, Lidiany Karla Azevedo RODRIGUES², Altair Antoninha DEL BEL CURY ${ }^{3}$, Emilena Maria Castor Xisto LIMA ${ }^{1}$, Renata Matheus Cunha Rodrigues GARCIA ${ }^{3}$

\author{
1- DDS, MSc, PhD student, Department of Prosthesis and Periodontology, Piracicaba Dental School, \\ University of Campinas (UNICAMP), Brazil. \\ 2- DDS, MSc, PhD student, Department of Physiological Sciences, Piracicaba Dental School, \\ University of Campinas (UNICAMP), Brazil. \\ 3- DDS, MSc, PhD, professor, Department of Prosthesis and Periodontology, Piracicaba Dental School, \\ University of Campinas (UNICAMP), Brazil. \\ Corresponding address: ALTAIR A. DEL BEL CURY - Av. Limeira, 901 - Piracicaba, SP - Cep.: 13414 - 903 (Brazil) \\ Tel. +55 193412 5294, Fax + 551934125250 - E-mail: altcury@fop.unicamp.br \\ Received: October 9, 2003 - Returned for modification: January 8, 2004 - Accepted: February 17, 2004
}

\begin{abstract}
$E$

xtracted human teeth are frequently used for research or educational purposes. Therefore, it is necessary to store them in disinfectant solutions that do not alter dental structures. Thus, this study evaluated the influence of storage solution on enamel demineralization. For that purpose, sixty samples were divided into the following groups: enamel stored in formaldehyde (F1), stored in thymol (T1), stored in formaldehyde and submitted to $\mathrm{pH}$ cycling (F2), stored in thymol and submitted to $\mathrm{pH}$ cycling (T2). All samples were evaluated by cross-sectional microhardness analysis and had their percentage of mineral volume versus micrometer (integrated area) determined. Differences between groups were found up to 30- $\mu \mathrm{m}$ depth from the enamel surface $(p<0.05)$, where samples from group T2 were more demineralized. It was concluded that the storage solution influenced the reaction of a dental substrate to a cariogenic challenge, suggesting that formaldehyde may increase enamel resistance to demineralization, when compared to demineralization occurring in enamel stored in thymol solution.
\end{abstract}

Uniterms: Storage solutions; Dental demineralization; Dental disinfection.

\section{RESUMO}

$D$ necessário o armazenamento dos mesmos em soluções desinfetantes que não alterem a estrutura dental. Para tanto, sessenta espécimes foram divididos nos seguintes grupos: esmalte armazenado em formol (F1), armazenado em timol (T1), armazenado em formol e submetido à ciclagem de pH (F2) e armazenado em timol e submetido à ciclagem de pH (T2), sendo avaliados por meio de análise de microdureza longitudinal e tiveram a porcentagem de volume mineral pro micrômetro determinada. Diferenças entre os grupos foram encontradas até a profundidade de $30 \mu \mathrm{m}$ da superfície do esmalte ( $<<0,05$ ), onde o grupo mais desmineralizado era T2. Foi concluído que a solução de armazenagem influenciou na reação do substrato dental a um desafio cariogênico, sugerindo que o formaldeído pode aumentar a resistência do esmalte à desmineralização promovida pelo modelo de ciclagem de $\mathrm{pH}$, quando comparado à desmineralização ocorrida no esmalte armazenado em timol.

Unitermos: Soluções de armazenagem; Desmineralização dental; Desinfecção dental.

\section{INTRODUCTION}

Studies on disinfection and sterilization progressed significantly during the last century, since many chemical and physical agents with antibiotic potential were discovered. These agents have been extensively studied $^{2,6,7,11,12}$, because of the risk, during medical or dental procedures, of cross infection and transmission of diseases such as AIDS and hepatitis B. However, dental professionals should be aware of the risk of cross infection not only by 
clinical procedures involving dental structures, but also for those carried out for research and educational purposes, which are extensively used in Dentistry.

Furthermore, an effective sterilization or disinfection method for extracted teeth ideally should not affect the structure or properties of dental substrates. Thus, it is important to identify methods for disinfection or sterilization of these substrates that will not alter their properties.

The Center for Disease Control and Prevention of the United States of America recommends that extracted teeth used for educational purposes should be disinfected with sodium hypochlorite or any other chemical germicidal solution ${ }^{13}$. However, it has been reported that sodium hypochlorite may increase enamel porosity by deproteneization ${ }^{3,10}$ and alter dentine structure, by removing or modifying the proteic matrix ${ }^{2,7}$, which could invalidate the use of teeth stored in this solution. Two other disinfectant solutions extensively used are $2 \%$ formaldehyde and $0.01 \%$ thymol $^{6,8,12}$, although there are no studies comparing the reaction of dental structures stored in these solutions in relation to experimental models involving cariogenic challenge, such as $\mathrm{pH}$ cycling. If a different reaction occurs among teeth stored in different solutions, comparisons between similar studies where teeth were stored in distinct solutions would be invalid ${ }^{12}$. Thus, the purpose of this study was to evaluate the influence of storage solutions - $2 \%$ formaldehyde and $0.01 \%$ thymol - on the cross-sectional microhardness and percentage of mineral volume in samples submitted or not to $\mathrm{pH}$ cycling.

\section{MATERIALAND METHODS}

\section{Experimental design}

This in vitro study involved caries induction by $\mathrm{pH}$ cycling, performed in one phase of 5 days. The factors under evaluation were: substrate at 2 levels: human enamel stored in $2 \%$ formaldehyde $(n=30)$ or $0.01 \%$ thymol $(n=30)$ for six months, and treatment at 2 levels: submission or not to $\mathrm{pH}$ cycling. Four experimental groups were obtained by the association of these two factors (2 substrates x 2 treatments): Group F1: enamel stored in formaldehyde; Group T1: enamel stored in thymol; Group F2: enamel stored in formaldehyde and submitted to pH cycling, and Group T2: enamel stored in thymol and submitted to $\mathrm{pH}$ cycling. Each group comprised 15 enamel blocks or experimental units $(n=15)$. All samples were submitted to cross-sectional microhardness analysis.

\section{Preparation of samples}

For this study, sixty human third molars were selected by visual inspection, according to the following criteria: $2 / 3$ of formed root, absence of enamel defects and carious lesions. Samples were cleaned by immersion of teeth in distilled water for 24 hours, hand scaling, and pumice and Robinson bristle. The middle third of the crown and root was cut-off with two parallel diamond discs separated by a 5-mm spacer, for the achievement of sixty enamel slabs including the cemento-enamel junction. Then, samples from groups T2 and F2 (groups submitted to $\mathrm{pH}$ cycling) were selected through the lottery method $^{9}$ and a round-shaped $2.5 \mathrm{~mm}$ diameter adhesive tape was stuck on the surface of each sample including the root-enamel junction. External surfaces around this area were covered with wax and acidresistant nail varnish. After the nail varnish dried, the adhesive tape was removed, exposing an enamel area of 4.9 $\mathrm{mm}^{2}$.

\section{Demineralization-remineralization cycling}

Control groups (F1 and T1) were kept in a closed, humid and refrigerated environment, while demineralized groups (F2 and T2) were submitted to five demineralizationremineralization cycles at $37^{\circ} \mathrm{C}$. In each cycle, samples were immersed individually for 3 hours in demineralizing solution ( $\mathrm{pH} 4.3$ ) and 21 hours in remineralizing solution ( $\mathrm{pH} 7.4$ ). The demineralizing solution composition was: Ca $2 \mathrm{mmol} / \mathrm{L}$, $\mathrm{PO}_{4} 2 \mathrm{mmol} / \mathrm{L} 0.75 \mathrm{mmol} / \mathrm{L}$ acetate, $0.03 \mathrm{ppmF}$ and the 6.36 $\mathrm{mL} / \mathrm{mm}^{2}$ proportion of exposed area was used. The remineralizing solution composition was: $\mathrm{Ca} 1.5 \mathrm{mmol} / \mathrm{L}, \mathrm{PO}_{4}$ $0.9 \mathrm{mmol} / \mathrm{L}, \mathrm{KCl} 1.5 \mathrm{mmol} / \mathrm{L}$, cacodilate $20 \mathrm{mmol} / \mathrm{L}, 0.05 \mathrm{ppmF}$ $\left(3.18 \mathrm{~mL} / \mathrm{mm}^{2}\right)^{1,5}$. Both solutions contained thymol crystals to avoid bacterial growth. Between each cycle, the samples were washed with deionized distilled water for 1 minute.

At the end of the $\mathrm{pH}$ cycling period, samples were rinsed with deionized water and cut in half vertically through the center of the lesion, with a diamond disc under water irrigation. One half of the slab was assigned for crosssectional microhardness and vol \% mineral measurement.

\section{Cross-sectional microhardness analysis}

One half of each sample was embedded in polyester resin so as to expose the cut aspect of the sectioned lesions. The exposed surface was flattened in a water-cooled mechanical grinder with \# 320, 400, 600 and 1,200 grit silicon carbide papers (CARBORUNDUN) followed by 1-mm diamond abrasive slurry (AROTEC). Cross-sectional microhardness analysis was performed by SHIMADZU (HMV 2000) microhardness tester with a Knoop diamond and a 25-g static load for 5s. The indentations were made in enamel at $800 \mathrm{~mm}$ from the root-enamel junction, at 10-, 30-, $50-, 70-\mu \mathrm{m}$ depth from the outer enamel surface.

\section{Percentage of mineral volume}

Microhardness values were converted into percentage of mineral volume using the following formula: $\% \mathrm{MV}=4.3$ $\mathrm{KHN}^{1 / 2}+11.3$, where $\% \mathrm{MV}$ represents the percentage of mineral volume and KHN represents Knoop hardness numbers ${ }^{4}$. Therefore, the percentage of mineral volume versus micrometer (integrated area) was calculated for each group ${ }^{4}$. 


\section{Statistical analysis}

The assumptions of equality of variances and normal distribution of errors were checked with Shapiro-Wilks tests for the response variables data: microhardness and percentage of mineral volume. The assumptions were satisfied and a two-way ANOVA was applied; differences between groups were assessed by Newman-Keuls test at the significance level of $5 \%$.

\section{RESULTS}

There were significant differences in microhardness values between samples stored in formaldehyde $2 \%$ and those either submitted to $\mathrm{pH}$ cycling or not, at $10-\mu \mathrm{m}$ depth (between F1 and F2) and from 10- to 30- $\mu \mathrm{m}$ depth between samples stored in thymol $0.01 \%$ and those either submitted to $\mathrm{pH}$ cycling or not (between T1 and T2). There were no differences among the four groups at other depths (TABLE I).

Analysis of the percentage of mineral volume versus micrometer showed statistical differences between groups stored in thymol (T1 and T2), indicating that the $\mathrm{pH}$ cycling model produced demineralization in this group. However, no differences were found between groups stored in formaldehyde (F1 and F2). Also, no differences were found between groups stored in different solutions that were not submitted to the $\mathrm{pH}$ cycling test (T1 and F1), but differences were found between the groups submitted to $\mathrm{pH}$ cycling (T2 and F2), with higher demineralization for the thymol group (TABLE I).

\section{DISCUSSION}

Disinfection of extracted teeth is essential to avoid cross infection during laboratory or research procedures.
However, the choice of the disinfecting agent must be based on its capacity of not altering dental structures or their reactions when submitted to experimental studies. One experimental model that is widely used to simulate a cariogenic challenge is $\mathrm{pH}$ cycling, which consists of immersing a sample in demineralizing and remineralizing solutions ${ }^{5}$.

In this study, the specimens' 3 hours of daily immersion in a demineralizing solution corresponded to the time of exposure to oral acidity below the critical $\mathrm{pH}$ of enamel dissolution. Immersion in remineralizing solution for 21 hours corresponded to the remineralization period to which a specimen would be exposed daily ${ }^{11}$. This $\mathrm{pH}$ cycling model was created by Featherstone, et al. ${ }^{4}$ (1986) and modified by Argenta $^{1}$ (2001) and was proven to be capable of altering Knoop hardness values in enamel. Fluoride was added to the solutions to reduce surface erosion caused by the acid exposure.

In this study, the results indicate the efficacy of $\mathrm{pH}$ cycling in demineralizing enamel only at $10-\mu \mathrm{m}$ depth for the formaldehyde group. However, demineralization was extended up to $30-\mu \mathrm{m}$ depth for the thymol group. The greatest demineralization in the thymol group was reflected by the percentage of mineral volume, where statistical differences were found between $\mathrm{T} 1$ and $\mathrm{T} 2$, but not between F1 and F2. The percentage of mineral volume between groups stored in different solutions did not differ statistically when not submitted to $\mathrm{pH}$ cycling ( $\mathrm{T} 1$ and F1), but differences occurred between samples from different groups submitted to $\mathrm{pH}$ cycling (T2 and F2).

These results indicate that the storage solution influenced the reaction of the enamel substrate to the $\mathrm{pH}$ cycling model used, where samples stored in formaldehyde presented a greater resistance to demineralization, which could be explained by the capacity of formaldehyde to fix proteins, such as those present in the organic pellicle attached to the surface of submerged teeth ${ }^{10,14}$.

TABLE 1- Means (standard deviation) of KNOOP microhardness and percentage of mineral volume $\mathrm{x} \mu \mathrm{m}$ (integrated area) of enamel stored in formaldehyde either submitted to $\mathrm{pH}$ cycling or not (F1 and F2) and thymol either submitted to pH cycling or not (T1 and T2) at 10-, 30-, 50-, 70- $\mu \mathrm{m}$ depth from the outer enamel surface

\begin{tabular}{lllll}
\hline Depth & \multicolumn{1}{c}{ Groups } & & \\
\hline & \multicolumn{1}{c}{ F1 } & \multicolumn{1}{c}{ T1 } & \multicolumn{1}{c}{ F2 } & T2 \\
\hline & & & & \\
10 & $275.9(21.1) \mathrm{Aa}$ & $188.0(83.0) \mathrm{Ba}$ & $173.4(65.7) \mathrm{Ba}$ & $119.2(48.9) \mathrm{Ca}$ \\
30 & $332.0(53.6) \mathrm{Ab}$ & $328.8(49.4) \mathrm{Ab}$ & $325.2(42.2) \mathrm{Ab}$ & $287.7(46.5) \mathrm{Ab}$ \\
50 & $339.8(37.9) \mathrm{Ab}$ & $333.6(41.6) \mathrm{Ab}$ & $345.3(43.9) \mathrm{Ab}$ & $335.5(46.5) \mathrm{Ab}$ \\
70 & $329.9(43.0) \mathrm{Ab}$ & $340.6(50.4) \mathrm{Ab}$ & $350.2(44.3) \mathrm{Ab}$ & $326.9(58.4) \mathrm{Ab}$ \\
$\%$ min vol. $\mathrm{X} \mu \mathrm{m}$ & $19,494.4$ & $18,535.2$ & $18,647.9$ & $16,925.6$ \\
& $(2,781.1) \mathrm{A}$ & $(1,963.0) \mathrm{A}$ & $(1,660.0) \mathrm{A}$ & $(2,046.8) \mathrm{B}$ \\
\hline
\end{tabular}

\footnotetext{
*Means followed by different capital letters differ statistically horizontally (between treatments)
}

**Means followed by different lower case letters differ statistically vertically (between depths). 
Consequently, this pellicle may act as a barrier to acid diffusion; therefore, its presence would make demineralization difficult by decreasing the concentration of demineralizing agents. In addition, the higher amount of protein in cervical enamel may make the demineralization process by acid solutions difficult. On the other hand, there are no reports on the literature about any effect from thymol on the protein structure.

In this study, the enamel surface layer was not removed, which could have influenced the depth of the lesion; in studies where such removal is carried out, there is a greater lesion depth caused by the $\mathrm{pH}$ cycling. This procedure removes 50 - to $120-\mu \mathrm{m}$ of the enamel surface and is carried out to remove possible interferences ${ }^{1}$. Thus, in further studies, it would be interesting to include groups in which removal of the enamel surface layer and polishing have been done, to verify the influence of such procedures on the storage solution used.

\section{CONCLUSIONS}

In conclusion, the storage solution influenced the reaction of a dental substrate to a cariogenic challenge. Formaldehyde may decrease the enamel demineralization promoted by a pH cycling model, when compared to demineralization occurring in enamel stored in a thymol solution.

\section{REFERENCES}

1- Argenta RMO, Tabchoury CPM, Cury JA. A modified pH-cycling model to evaluate fluoride effect on enamel demineralization. Pesqui Odontol Bras 2003;17(3):241-6.

2- Barbosa SV, Safavi KE, Spanberg LSW. Influence of sodium hypochlorite on the permeability and structure of cervical human dentine. Int End J 1994; 27:309-12.

3- Bitter NC. A scanning electron microscopy study of the effect of bleaching agents on enamel. J Prosthet Dent 1992; 67(6):852-5.

4- Featherstone JDB, ten Cate JM, Shariati M, Arends J Comparison of artificial caries-like lesions by quantitative microradiography and microhardness. Caries Res 1983; 17(5):385-91.

5- Featherstone JDB, O’Reilly MM, Shariati M, Brugler S Enhancement of remineralisation in vitro and in vivo. In: Leach S.A. Ed. Factors relating to demineralisation and remineralisation of the teeth. IRL Press; 1986. p. 23-34.

6- Goodis HE, Marshal GW, White JM. The effects of storage after extraction of the teeth on human dentine permeability in vitro. Arch Oral Biol 1991; 36(8):561-6.

7- Inaba D, Duschener H, Jongebloed W, Takai O, Arends J. The effects of a sodium hypochlorite treatment on demineralized root dentin. Eur J Oral Sci 1995; 103(6):368-74.

8- Kern M, Fechitig T, Strub SR. Influence of water storage and thermal cycling on the fracture strength of all-porcelains, resin bonded fixed partial dentures. J Prosthet Dent 1994; 71(3):251-6.
9- Leedy PD. Practical research planning and design New Jersey, $6^{\text {th }}$ edition ed. 1997.

10- Robinson C, Hallsworth AS, Shore RC, Kirkhan J. Effect of surface zone deproteinization on the access of mineral ions into subsurface carious lesions of human enamel. Caries Res 1990; 24(4):226-30.

11- Rodrigues LKA. Carga bacteriana de dentes humanos e efeito da radiação gama sobre o esmalte dental. Piracicaba 2002: [Dissertação de Mestrado - Faculdade de Odontologia de Piracicaba - UNICAMP].

12- Tate WH, White RR. Disinfection of human teeth for education purposes. J Dent Educ 1991; 55(9):583-5, 1991.

13- Toro MJ. In vitro fluoride dose-response study of sterilized enamel lesions. Caries Res 2000; 34:246-53.

14- Wheatherell JA, Robinson C, Hallsworth AS. Changes in the distribution of fluoride in enamel surface of human teeth. Arch Oral Biol 1973; 18(9):1175-89. 